\title{
Morocco: An Informal Passage to Literacy in dārija (Moroccan Arabic)
}

\author{
Dominique Caubet
}

In this contribution, I shall deal with a recent development in keyboard-toscreen communication in därija (Moroccan Arabic). I postulate that qualitative change is taking place and that we are now reaching a stage where a further step is being crossed, from the passage to writing and deciphering that took place from the early 2000s, to literacy proper.

From the late 1990s and the beginning of the 2000s, the new technologies have allowed a spontaneous passage to writing for a language variety that has not been codified. It was led by actors from civil society who, slowly but steadily, taught themselves to read and write in dārija, with a true D.I.Y. (Do It Yourself ${ }^{1}$ ) spirit. This writing is 'informal', in the sense of taking place in the 'informal sector', i.e. first, outside of state control or regulation, and second, with the 'coping' behaviour of individuals who take over when the institutions are absent (by 'coping' I mean taking responsibility and initiative at their level).

\section{The First Steps}

In Morocco, it started within two different networks. One was the small circle of initiates who used $m I R C,{ }^{2}$ an Internet Relay Chatting system for computers, from the end of the 1990s. The other started in 2001 with the use of sMs on mobile phones, and rapidly developed for a wider audience (see Caubet 2004). With $m I R C$, people learnt to chat in Latin script, the only option available on computers at the end of the gos. It was later replaced by a more popular web-based instant messaging device, msn (Windows Live Messenger), through which people could chat for hours, connecting from cyber-cafés, since very few

1 DIY, Do It Yourself, the attitude developed by the punk subculture in the 7o's.

2 See http://www.mirc.com and for North Africa, see Berjaoui 2001 for Morocco and Babassi 2004 for Algeria. 
could afford to buy a computer and have a connection at home; this went on from 2005 to 2010 . Unlike Facebook, the early chat systems provided users with anonymity.

Mobile phones also gave people independence - especially girls, who could exchange text messages, whereas they were not allowed to go to cyber-cafés, which sounded like "cafés" in the eyes of their families. Even for those who were not fluent in reading French, mastering the Latin alphabet could be reinvested in writing short messages in dārija (see the case studied in Caubet 2004).

\section{Dārija: A Change in Practices and Status in the Civil Society}

Dārija has undergone a drastic change in practices and status in the Moroccan emerging civil society, while the institutions completely failed to follow suit.

Practice first came in the form of a passage to writing on first-generation mobile phones in Latin script. This choice was not ideological, but practical, because the only available phones and computers at the time were equipped with French keyboards. In 2006, the same young people who wrote dārija in Latin script on keyboard-mediated exchanges, when given a pen, would instinctively write in Arabic script (see Caubet 2012). They would use a different script (Latin $v s$ Arabic), whether they wrote on a piece of paper or on a keyboard. At the time, older people would either not be aware of - or despise these practices.

Status came slightly later and was influenced by the development of these practices. Voices started to claim that dārija was a key element for the definition of a new Moroccan identity, being the language that unites all Moroccans. Such voices came from a social and cultural movement which emerged in the early 20oos and was compared to the Spanish Movida. Nayda ${ }^{3}$ was the name given to a cultural effervescence that took place during the years $2005^{-2008}$.

However, the key year is 2003, when two dramatic episodes contributed to change the course of events: first, the arrest of 14 young heavy metal music lovers, their trial in February 2003, and the public mobilisation that followed; second, on May 16, seven simultaneous kamikaze fundamentalist bombings involving 14 youngsters from a neglected neighbourhood in Casablanca (Sidi

3 Nayda is the active participle of the verb nad "to rise"; it was an expression used in youth language "it's moving, it's rocking", and it became the name of the Moroccan Movida (see Caubet 2010b). 
Moumen), causing the death of 33 people (apart from themselves), and leading to massive public questioning in Moroccan society. As a consequence, the 'legal' fundamentalists (the present Prime Minister's party, the PJD) disappeared from the political life for a whole year and brought a breath of freedom. This is when the underground movement started to grow on the public scene until it became a socio-cultural movement, and was heavily mediatized from 2006 (see Caubet 2007, 2008, 2010a and the documentary Casanayda!). ${ }^{4}$ Därija played a central part in the artistic productions of this new music scene, and artists claimed that it was their language and that they were proud of it. Dārija was a means to convey things in a more Moroccan way, to try and speak the language of the people.

The status of dārija has changed radically in the last ten years: it had been associated with illiteracy, backwardness and was considered incompatible with education or progress. Now it has become trendy and modern, considered as the language capable of accompanying the Nayda. At the same time, fierce debates about the official use of dārija in the schooling system have been going on since October 2013. This is in itself significant: while institutions seem to have rejected dārija once again, the fact that the question has been raised and discussed at length is a sign of change. ${ }^{5}$ One also should not underestimate the fact that the absence of an institution and official formatting may present an opportunity for boundless communicative freedom and creativity.

For writing in Latin script, techniques have been described (Benitez Fernández 2012, Caubet 2013, Moscoso 2009), noting variation in writing between 'scriptors' and even for the same writer. But over the years, people have taught themselves to write and to read (in that order), acquiring a high level of fluency that I wish to describe as a 'passage to writing'. The phenomenon is so important that it is mentioned in columns, like Zakaria Boualem in Telquel weekly by Reda Allali; on February 21, 2016, in a paper called "Zakaria Boualem et l' école en français, ${ }^{\prime 6}$ he writes:

Pendant que des commissions se penchent tous les jours, et que des théoriciens glosent, sur les choix stratégiques, des millions de Marocains, chaque minute, s' écrivent en dārija avec des chiffres et des lettres parce qu' on refuse de normaliser ce qui devrait être notre langue.

4 A film written by D. Caubet, directed by F. Benlyazid and A. Mettour, Sigma, Casablanca 2007, in six episodes on youtube https://www.youtube.com/watch? $\mathrm{v}=\mathrm{aRrTizRzmFQ}$.

5 For this debate, see Miller 2014 and Caubet \& Miller 2016.

6 http://telquel.ma/2016/o2/21/zakaria-boualem-lecole-en-francais_1483687. 
While commissions address and theoreticians gloss daily on strategic choices, millions of Moroccans, exchange every minute in dārija, using numbers and letters because (the authorities) refuse to normalize what should be our language.

Although it was technically possible to write in Arabic script from 2009, with the Facebook Arabic interface, it takes time to change practices. But when people do switch to using Arabic, they also undergo what I will term a 'passage to literacy'. Thus, in 2014-2016, I observed a passage from the stage of plain writing and deciphering dārija to that of an ability to comprehend and express longer, elaborate, and even literary, texts.

\section{The Arabic Script: Literacy on Smartphones and Computers}

For the general public and internet users, the passage to the Arabic script is recent and slow, simply because people find it difficult to type in Arabic. Nowadays however one can download an application that provides an Arabic keyboard for smartphones, which makes it easier. By the end of 2009, out of a million users, $85 \%$ used the French interface and only $6.5 \%$, the Arabic one (Tancrez 2009). In 2012, the French interface had gone down to $76 \%{ }^{7}$ - and it remained at $75 \%$ in $2014,{ }^{8}$ with 7.2 million profiles; more recently, the use of Arabic went up: from $17 \%$ at the end of 2012 to $33 \%$ in 2014. The figures adding up to more than $100 \%$ - show that a number of people use both French and Arabic interfaces.

By the end of 2009, 25 million mobile phone subscribers had sent 2.85 billion text messages. ${ }^{9}$ The corresponding figures for 2011 were 36.5 million/over 5 billion SMS, and for 201342.4 million/over 11 billion SMS. Just a comparison and a reminder about the situation ten years previously, in 2003: the number of SMS was estimated at $55^{\circ}$ million, for 7.3 million mobile phones (see Caubet 2004).

Internet penetration went up tremendously in one year, reaching $30 \%$ at the end of 2014, up from $17 \%$ in 2013.

7 For the 2012 figures, see https://eplume.wordpress.com/2011/07/2o/les-reseaux-sociaux-au -maroc-et-dans-le-monde-arabe-twitter-facebook-statistique-etude-du-printemps.

8 The last available figures are for 2014: http://www.usinenouvelle.com/article/les -marocains-toujours-accros-a-facebook-mais-retifs-a-twitter.N272945.

9 All the following figures are taken from the annual reports of the ANRT, and can be found at anrt.ma. 
TABLE 5.1 Nb of sMs / Nb of mobile phones - D. Caubet from ANRT figures

\begin{tabular}{lll}
\hline Year (end of) & $\begin{array}{l}\text { Number of mobile } \\
\text { phones subscribers }\end{array}$ & Number of sMs issued \\
\hline
\end{tabular}

\begin{tabular}{lll}
2003 & $7 \cdot 3$ million & 550 million (estim.) \\
2009 & 25 million & 2.85 billion \\
2011 & 36.5 million & 5 billion \\
2013 & 42.4 million & 11 billion \\
2014 & 44.1 million & 19.7 billion \\
\hline
\end{tabular}

With the development of Arabic keyboards on smartphones and computers, people started using the Arabic script, but less so than Middle Eastern countries; while Morocco had reached $33 \%$ of the Arabic interface on Facebook at the end of 2014, Egypt already had 60\% in May 2012. ${ }^{10}$

Recent figures give 12 million Facebook subscribers in Morocco in June 2016, with a $35.5 \%$ penetration rate for Facebook (See table 5.2 below).

To switch from a system of writing you master to another one, you need to have a strong motivation: either you find it easier to write in Arabic, or there are new technical possibilities (Arabic interface for Facebook and Arabic keyboards on smartphones), and your social network (your friends) is also switching to Arabic. But it may also be that you have made a political decision to write in dārija in Arabic script, because this is how your message will be conveyed to a maximum of people who are not really at ease reading Standard Arabic or French. Another reason, more political, is the idea of access to the people, in a post-'Arab spring' climate. The writers I interviewed are convinced that if you want to reach the people, you must write dārija in Arabic script, and this is what they have decided to do when posting on Facebook or when writing longer texts on a blog. They write in dārija for the following reasons: in order to be understood; because it is rich and authentic (hit ganya $u$ așila), because it is very powerful (qwiya); because you cannot lie to the people by using lughat l-khashab (< Fr. "langue de bois", i.e. political cant).

10 See http://www.spotonpr.com/facebook-arabic-triumphs: this is the last data available on the question and it has probably grown in Morocco in 2016. 
TABLE 5.2 Facebook penetration. Established with 2016 figures from Internet World Stats. ${ }^{11}$

\begin{tabular}{lrrc}
\hline Country & $\begin{array}{r}\text { Population } \\
\text { (2016 Est.) }\end{array}$ & $\begin{array}{c}\text { Facebook } \\
\text { subscribers } \\
\text { 30-June-2016 }\end{array}$ & $\begin{array}{c}\text { Facebook } \\
\text { penetration } \\
\text { rate (\%) }\end{array}$ \\
\hline Algeria & $40,263,711$ & $\mathbf{1 5 , 0 0 0 , 0 0 0}$ & $37 \cdot 2$ \\
Egypt & $90,067,793$ & 32, ooo,ooo & $35 \cdot 52$ \\
Iraq & $37,547,686$ & $\mathbf{1 4 , 0 0 0 , 0 0 0}$ & $37 \cdot 28$ \\
Lebanon & $5,988,153$ & $3,100,000$ & $52 \cdot 7$ \\
Morocco & $\mathbf{3 3 , 6 5 5 , 7 8 6}$ & $\mathbf{1 2 , 0 0 0 , 0 0 0}$ & $\mathbf{3 5 . 6 5}$ \\
Saudi Arabia & $32,157,974$ & $\mathbf{1 4 , 0 0 0 , 0 0 0}$ & $43 \cdot 53$ \\
United Arab Emirates & $9,266,971$ & $7,700,000$ & 83 \\
Tunisia & $\mathbf{1 1 , 1 3 4 , 5 8 8}$ & $5,800,000$ & 52.1 \\
\hline
\end{tabular}

Some of the authors I have been following for over two years had a link with the 2oth February movement (\#Feb2o); not with the more politicized students who would use Standard Arabic, the language of politics, but with the oulad cha3 $b$ of more popular origin. Some of them have been jailed on fallacious pretexts, like Mouad L'7aged who spent one year and eight months in jail over a period of three years, ${ }^{12}$ or Mohamed Sokrate, a blogger who was sentenced to two years in June $2102 ; 13$ a sign that shows how disturbing they were for the system. Others were members of the Feb2o lejnat el-ibda3 (Creative Committee).

\section{New Literacy: Examples of Elaborate Texts}

The idea of writing and reading in dārija has become commonplace and does not constitute a problem any longer in civil society. The general attitude is 'informality' and 'tolerance', and the absence of an official norm gives total

11 Figures for Africa and the Middle East: see http://www.internetworldstats.com/africa.htm \#ma and http://www.internetworldstats.com/stats5.htm.

12 From Sept. 2011 to Sept. 2014; for more information, see http://www.npr.org/2012/01/o6/ 144798285/rappers-imprisonment-tests-moroccan-reforms and http://www.theguardian .com/commentisfree/2012/apr/17/el-haqed-morocco-hip-hop-revolutionary. In January 2016, he asked for political asylum in Belgium, which he was granted in February 2017.

13 For more information, see http://www.freearabs.com/index.php/society/81-stories/1073 -jb-span-profile-jb-span-the-arab-bukowski and Caubet forthcoming 2017. 
freedom to the writers, as to which script to choose. No one is being reproached for his choice or for his spelling; everyone naturally understands the others without raising any issue.

What I present here is new material that I have been collecting since 2014; I witnessed a qualitative change in the texts published on the internet: writing of long elaborate prose texts in dārija, passing from basic communication to literacy proper.

What is remarkable is the massive character of the process - which concerns millions of youths in Morocco, and in the Arab world - for languages without any official recognition, and whose status is given by the civil society and not by the state. I will present three authors: 1) rapper Mouad L7agd, 2) blogger Harabish and 3) slammer Mustapha Slameur (for a wider range of authors, see Caubet forthcoming 2017).

\section{Mouad}

Mouad is a rapper, but in February 2015, he published two stories, "T7arbichat" number one and two, ${ }^{14}$ where he writes about his memories of the first demonstration of February 20, 2011. The title comes from "7arabich", i.e. the name the members of the lejnat el-ibda3 (Creation Committee) of the Feb2o chose for themselves. We will also see texts by a close friend of his, who blogs under the name Harabish (see below).

In late 2015, Mouad decided to leave Morocco and come to Europe, because it was impossible for him to express himself there: well-known as he is, he had not been able to perform in a concert of his own; they were all banned. The only times he went on stage was when he was invited unannounced by fellow rappers, like L'Moutchou (Mobydick). ${ }^{15}$ The general tendency is not towards solidarity with Mouad L7agd among rappers, and very often on the two-faced grounds that he is not a good rapper ...

In Belgium, he wrote more prose texts and on 13 February 2016, he announced the publication on his l7agd page: "Stay tuned for Mouad l7agd's exclusive diary on goud.ma":

\section{ترقبوا مذكرات معاد الحاقد حصريا على كُود}

The series is published under the title "Men zokacha 1 Molenbeek" (From Okacha to Molenbeek); the publication started on 18 February 2016 and came out regularly two or three times a week (parts 1 to 15).

\footnotetext{
14 Text 1 has 464 words, 2413 signs; T7arbichat means stories about 7 arabich guys.

15 See https://www.facebook.com/lmoutchou/?fref=ts.
} 


$$
\text { من عكاشة المى مولنبيك, مذكرات معاد الحاقد }
$$

With the present text, we are witnessing his first steps in the domain of writing.

This extract is the second part of T7arbichat number 1 (in bold the terms whose spelling will be discussed below):

$$
\begin{aligned}
& \text { كنقول مع راسي ليوما غيسالي هاد شي، خاصها تشعل خاصنا نغوتو، صاف مشا وقت }
\end{aligned}
$$

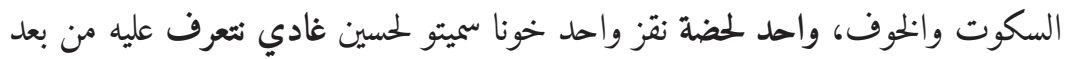

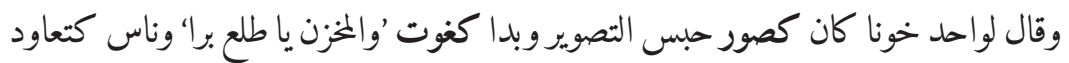

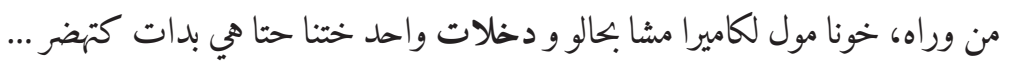

kangol m3a rasi lyoma gha ysali had ši, haașș-ha tšezl, haș̣s-na nghowwto, șafi mša wegt s-sokut w-el-ȟof; wa7ed l-le7ḍa neggez wa7ed huona smiyto le7sin, ghadi netezrref 3li-h men be3d, o gal l-wa7ed hona kan kișowwer '7bes et-teșwir!' o bda kighowwet 'O l-mahzen yṭlez berra!' o n-nas kat3awed men oura-h, hona mol l-kamira mša b7alo o dehlat wa7ed hyetna 7ta hiya bdat katehḍer?

I said to myself, all this is going to end, it must stay lit, we must shout; the time of silence and fear has ended. And in an instant, a guy named Lhocine - whom I would get to know later - jumped up and he told a guy who was filming 'Stop filming!' and he started to shout 'Let the Makhzen leave!' and people repeat it after him; the guy with the camera went home and a girl came in, and she too started to speak.

$$
\begin{aligned}
& \text { واحد اللحضة كيبان لينا لبيثان ولميكروات كتبرونشاو وتجمع تقريبا كلشي فالقنت ليسر ديال }
\end{aligned}
$$

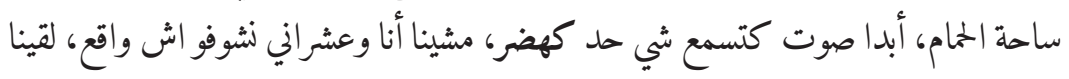

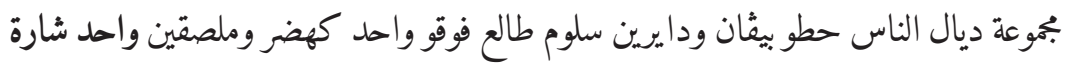

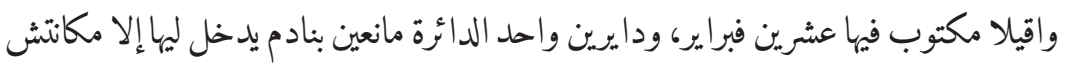

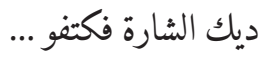

Wa7ed el-le7ḍa kayban li-na l-bigab (pick up) o l-mikruwat kitbranšaw (> Fr. brancher) o tejme3 tegriban kolši f-el-gent l-liser dyal sa7at l-7mam, o bda șot kattesmez ši 7edd kiyhḍer; mšina ana o zešrani nšofo aš wage3, lgina mejmoza dyal n-nas 7etțo bigab o dayrin sellom țalez fogo, wa7ed kihḍer o mleșsgin wa7ed šara wagila mektub fi-ha 20 feb, o dayrin wa7ed d-da2ira mânzin bnadem ydhel liha ila ma kanetš dik šara f-ktafo ... 
After a while, we saw the van and mikes being plugged in, and nearly everyone gathered on the left corner of the Pigeon Plaza, and a voice could be heard, someone speaking; I went with my friends to see what was happening, we found a group of people who had brought the van and put a ladder to climb on top, and a guy talking; they all had stuck badges that said $20 \mathrm{Feb}$, and they had formed a circle, forbidding people to get in if they were not wearing that badge on their shoulder ...

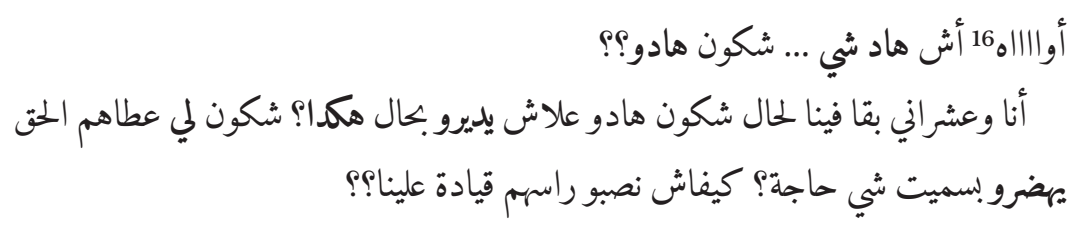

Awwaaah, aš had ši ... škon hadu? Ana o zešrani bya fina l7al; škon hadu 3laš idiro b7al hakka? Škon lli 3țahom l7eg9 yheḍro b-smiyt ši 7aja? kifaš naḍo ras-hom giyada 3lina?

Heyyy, what's this? Who are these guys? We didn't like it, my friends and me ... Who are they? Why are they doing this? Who gave them the right to speak in the name of a movement? How did they find themselves ruling over us?

$$
\begin{aligned}
& \text { بدينا كنغوتو أنا وعشراني، معجبناش ديكور ... بدينا مطلعينا عليه بالشعارات، هو يبي لعندنا } \\
& \text { واحد خونا كان حتا هو داير شارة ... }
\end{aligned}
$$

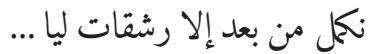

Bdina kanghuwwto, ana o zešrani, ma jjebnaš d-dikor ... bdina mțell 3 ina 3lihom b š-šizarat, howa yji l-zend-na wa7ed hona, kan 7ta howa dayr šara ...

nkemmel men be3d ila rešgat lina ...

We started shouting, my friends and me, we weren't pleased with the situation, we started provoking them with their slogans, so one guy wearing a badge came up to us

I shall go on later, if it pleases us ...

16 Expressivity is also marked by duplication of letters in Arabic script. 
He actually published a series of 23 texts between February and May 2016 on goud.ma.

\section{Harabish}

Harabish, the author of the blog zarbichat men l-bo3d laher ("7arbichates"17 from another dimension), is a very close friend of Mouad and he has engaged with him in artistic projects. He is present on several clips and has recorded a number of tracks with him since his 2014 album, Waloo والوووا "Nothing”;18 his voice is more on the reggae side.

Previously, he was trained as a blogger in Casablanca for a project entitled "Reinforcing the capacities of Arab bloggers and journalists for the promotion of Human Rights", in 2013 by the Arab Institute for Human Rights, ${ }^{19}$ a regional NGO based in Tunisia. His blog won one of the three awards presented on 14 December 2013 in Tunis. His idea was to blog in his own language, as Harabish puts it:

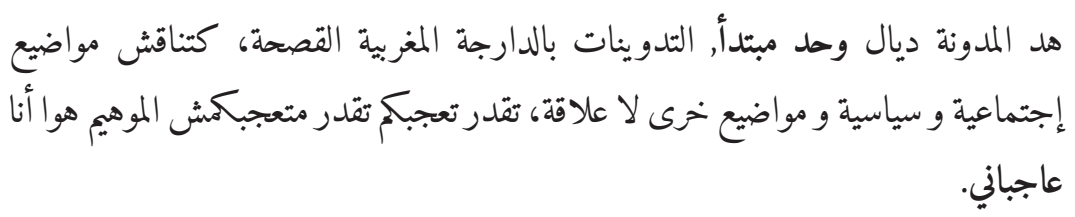

Had-el-mudawana dyal wazed mubtada2, t-tadwinat b-ed-dārija elmag̉ribiya el qaș7a, katnagech mawaḍiz ijtimaziya o siyasiya o mawaḍiz hora la 3laga, tegder tejjbek tegder ma tejjbek ch, el-mohimm howa ana 3ajbani.

This blog is the work of a novice; the entries are written in harsh Moroccan Arabic; it deals with social and political issues, and also with other subjects that have nothing to do with this. It may appeal to you and it may not appeal to you; anyways, what's important is that it appeals to me.

17 Stories by a 7arabich, i.e. a member of Feb2o Creation committee.

18 See the tracks on https://www.youtube.com/watch?v=WGFprugyoso.

19168 bloggers were trained coming from nine Arab countries from February 2012 to January 2014 by the Arab Institute for Human Rights; Harabish created his blog during the training and went on writing. In the following report, this training is developed; see particularly p. 4:

http://www.un.org/democracyfund/sites/www.un.org.democracyfund/files/UDF -RAS-10-369_Evaluation_Arab\%2ostates.pdf. 
The blog counts 29 texts (20,700 words). It has been running since 26 February 2013 and the last text was posted on 3 August 2015. When a new text is posted, it gets over a thousand readings, according to Harabish.

We'll present two extracts from a text called مشاهد (scenes),, ${ }^{20}$ where he makes abundant use of understatement, humorously stating in fous7a that nothing is true: "لا شيء حقيتي

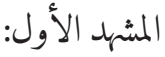

$$
\begin{aligned}
& \text { دخل للكوميسارية، قصد البيرو ديال الشاف و كُاليه (ملي الشاف شاف فيه بواحد }
\end{aligned}
$$

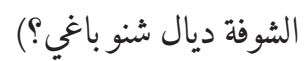

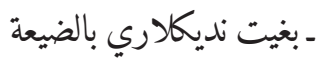

$$
\begin{aligned}
& \text { الشاف: شنو ضاع ليك؟ } \\
& \text { ـ ضاعت شي حاجة سميتها وطن }
\end{aligned}
$$

El-mašhed l-uwwel:

Dhel le-l-komisariya, qșed l l-biro dyal š-šaf o gal lih (melli š-šaf šaf fih b wa7ed š-šofan dyal šno bagii?)

- Bg̈it n-diklari (< Fr. déclarer) be-ḍ-diyza

Š-šaf: šno ḍaz lik?

- ḍazet ši 7aja smiytha "wațan"

\section{Scene one:}

He went in the police station and went directly to the chief's office (when the chief gave him a look that meant: what does he want?)

- I want to declare a loss

The chief: What have you lost?

- What is lost is something named "homeland"

$$
\text { ـ المشهد التاني: }
$$

20 Published on 21 April 2015. The complete text counts 546 words. 


$$
\begin{aligned}
& \text { ـ حتى هو بقا كيشوف فيها حيت ع فها، هي البنت لي عندو فلائحة الأصدقاء فالفايسبوك، } \\
& \text { ولي ديما كتكتب حول موضوع المساوات بين الراجل و المرأة وبلي راهم بحال بحال لي يديرو } \\
& \text { الراجل ديرو تاهي. } \\
& \text { ـ مازال كتشوف فيه تاهي و حسات بلي ركز معاها بزاف و هو كيشوف فيها. } \\
& \text { ـ تلف بزاف و مابقاش عارف شنو يدير. } \\
& \text { ـ حسات بيه متوتر بزاف و مابقاش مرتاح. } \\
& \text { ـ ما لقى مايدير جبد كتاب من شكارتو و بدى كيقرا فيه باش مايبقاش يشوف فيها و هي } \\
& \text { كدير فيه شوفت المش الجيعان، باش ينوض و يخليها تكلس فبلاصتو حيت كاين الزحام، و } \\
& \text { حيت غتعيى بزاف حيت هي غير بنت. }
\end{aligned}
$$

El-mešhed t-tani:

(Mešhed: Samt, lmakan: țobis zamer bezzaf o lli wagfin kter men lli galsin)

- țelzat le-ț-țobis o bgat katšof fih.

- 7ta howa bya kayšof fiha 7it 3refha, hiya l-bent lli zendo fel-lazizat al-2asdiga fel-faycebook, o lli dima katkteb 7awl mawḍu el-mosawat bin r-rajel o le-mra o belli rahom b7al b7al, lli idiro r-rajel, tdiro ta hiya.

- ma zal katšof fih ta hiya o 7essat belli rekkez mazha bezzaf o howa kayšof fiha.

- tlef bezzaf o ma bgaš zaref chno ydir.

- 7essat bih metwutter bezzaf o ma byaš merta7.

- Ma lga ma idir, jbed ktab men škarto bda kaygra fih baš ma yebgaš yšof fiha o hiya katdir fiha šofat el-mešš le-jizan, baš ynoḍ o yhalliha tegles f-blașto 7it kayn ez-z7am o 7it gatzani bezzaf 7it hiya gir bent.

\section{Scene two:}

(Scene: silence; place: a very full bus where more people are standing than seating)

- She climbed on the bus and she kept staring at him.

- He too, started looking at her, because he knew her; she is the girl he has on his list of friends on Facebook, who is always writing about the subject of equality between man and woman, and that they are the same: what man does, she can do it too.

- She goes on staring at him because she felt that he is thinking of her and that he is staring at her.

- He was lost and did not know what to do. 
- She felt that he was very tense and he was not at ease anymore.

- He did not find what to do, so he picked up a book from his bag and began to read, in order not to look at her anymore; she was giving him a hungry cat's look for him to get up and let her sit in his place, because there was a crowd, and it would take care of her, because she is a girl ...

Harabish sometimes posts long texts or extracts form his blog texts on his Facebook profiles on which he has nearly 5000 "friends". He is a student and it is not always simple for him to connect, with very little means to do so.

\section{Slam Poetry}

Slam Poetry or 'Spoken Word' is poetry in performance; it started in the 199os in the United States with African-Americans poets who were explicitly following what the Beat Generation and the "Négritude" poets had done previously when they declaimed their texts. ${ }^{21}$

El Mssati, when he organized Café Slam in February 2015, gave a good definition of Spoken Word for young Moroccans using youth language and comparing it to rap: ${ }^{22}$

hint slam ra machi howa lketba, slam ra howa dek stoon lli, fech katkoun tale3 open mic o kat7awel tzaber zla dek text lli nta katbo, o fech katbghi tsejlo, tgder tsemih Spoken word. Poetry ... (his original spelling)

because slam is not just writing, slam is that stuff where, when you go on stage for an Open Mic, and you're trying to recite that text that you wrote and when you want to record it; you can call it Spoken word. Poetry ...

He organized a Thé Slam in $2016,{ }^{23}$ and this is how he addressed the potential poets (original writing), and what were the languages at stake (sic: their original spelling):

Vas-y Parle.. B'dārija TKLM personne ne te stopera! Le Micro est ouvert pour tous ceux qui souhaite déclamer, partager leur poésie, leur texte et leur état d'ame en toute libérté loin de toute censure; que ça soit en darija, francais, anglais ou meme bien japonais venez nous faire part de

\footnotetext{
21 See https://www.poets.org/poetsorg/text/brief-guide-slam-poetry.

22 For the complete text, see Caubet forthcoming 2017.

23 https://www.facebook.com/events/1743195605924179.
} 
votre poésie. Nous vous donnons RDV le samedi 13 fevrier à l' Espace "Les Artistes" Rabat (Café-Restaurant). ${ }^{24}$ (sic)

$$
\begin{aligned}
& \text { يالاه هدر ... تكلم تاحد ماغايحبسك! هادي هي الفرصة باش اي واحد باغي يعبر، يشعر و }
\end{aligned}
$$

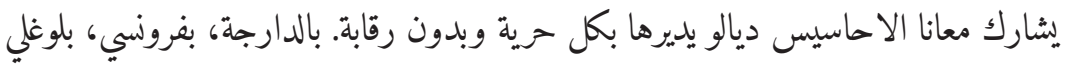

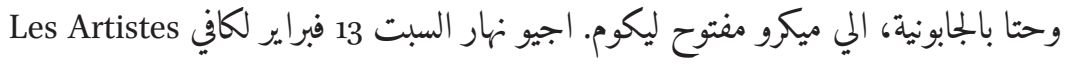

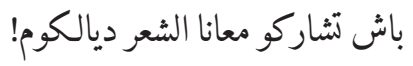

Poets compete with intense emotion during public Slam sessions. This genre is very new in Morocco and is found more in the form of videos posted on internet than performed live, due to the lack of events. The languages used can be MSA, French but mostly dārija, sometimes with some codeswitching.

Mustapha Slameur is a former rapper who started very young in the late 9o's under the name Steph Raggaman. He began slamming around 2012 and he was the first to publicize this art on the social networks where is very active. He regularly posts videos of slam texts on his youtube channel, Le Slam de Mustapha. In 2015 he initiated slam workshops at the Institut Français of El Jadida, the town where he works as a teacher. On his Facebook profile, he regularly posts long texts or very short videos giving his point of view, or defending street arts in general, and a street artist from Algiers in particular (January 16, 2016). He has texts in French, and more recently in Standard Arabic (because he aims at Francophone and Arab audiences), but the language he uses most naturally is dārija, which he calls ${ }^{25}$ "al-Magharibiya; en référence au Maghreb. A la base on n'est pas des Arabes, mais des Maghariba, Tunisie, Algérie, Maroc", referring to the Maghreb and not just Morocco. And he adds, defining the language: "Donc forcément il y a des mots en français; une super grande ouverture sur l' espagnol".

24 Come on! Speak up, in Dārija, TKLM (talk), no one will stop you! The mike will be open to all those who want to declaim, to share poetry, their text and their state of mind in complete freedom, far from any censorship; whethet in Dārija, French, English, or even in Japanese, come and share your poetry. We'll be happy to meet you ... Transcription of Dārija: Yallah, hder, tkellem, ta 7ad ma ġayebsek! Hadi hiya el-forSa baš ey wajed baġi yezbber, yešre 3 o yšarek m3ana el-7asis dyalo ydirha b-koll yoriya o bidon ragba. B-ed-dārija, b fronsi, b-lonġli o 7ta b-el-jaboniya, ila micro mefto likom! Ajio biha ssebt 13 febrayer l Café les Artistes baš tšharko mзana š-šezr dyalkom.

25 All the quotations come from an exchange we had on facebook messenger, 18 January 2016, mostly in French. "Initially, we're not Arabs, but 'Maghariba' (Maghribians)". "So inevitably there are French words; a great opening on Spanish". 
Slameur claims the right to mix languages, because a) it is common in North Africa; and b) as an artist, who defines himself as a 'rime hunter': "Je suis un chasseur de rime. Entre arabe, dārija, espagnol ou français, Je me sers. La sonorité prime et les mots ont une charge $f$ le sens spécial qui donne forcément un punch aux phrases." ${ }^{26}$ He also uses English (see below). When he reads out his texts, this mixing is extremely well-done and sounds perfectly natural, and very dramatic as is the habit with Slam. He does not publish his texts apart from the videos. The lyrics have to be found on internet and for the title chosen here, it was published by Don Badr. ${ }^{27}$ Nevertheless, we will examine the way this person writes dārija.

Slam is by definition 'spoken word' and, unlike the previous texts, it is not meant to be read. I am including it as a form of elaborate text, composed by an author. Apart from Mustapha, young artists have emerged in 2014 or 2015, like Hamza El Mssati (whom we saw above) or girls, like Salma and Loubna, who post videos regularly. ${ }^{28}$ I chose to give long extracts of a text. ${ }^{29}$ It is the first of a series called 'Taire-bouche'30 (a word play with the Moroccan word terbuš "Fez, brimless cap”, and the French 'Taire bouche' [lit. hush up-mouth]) a collaboration with three other authors who are rappers, L'Morphine, Mehdi Black Wind and Magma (published in September 2014, counting over 251.000 views in February 2016). Mustapha speaks against injustices, corruption, the lack of social equality, the lack of trust in politicians, etc.; all these themes are also present in some rap texts (see Caubet 2010b). His motto, printed on T-shirts, is self-explanatory: kedbou zlina ... كذبوا علينا "they lied to us". This is an extract of Mustapha Slameur's piece; I must thank Mustapha for the help he gave me for the translation:

26 "I am a rime hunter. I help myself to Arabic, Darija, French, Spanish. The sound has priority and gives words a load in a special sense, and it inevitably adds some punch to the sentences."

27 The lyrics, as published by Don Badr, count 420 views: https://www.youtube.com/watch ?v=4afbLTUIS2Q.

28 For Salma Slameuse, see https://www.youtube.com/watch?v=VPDn_JSNnTs; for Loubna La Slameuse, see https://www.youtube.com/watch?v=sKo_WSmJChU, where we get a glimpse of her note book, which shows that she writes Dārija by hand in Latin script; for Mssati, see https://www.youtube.com/watch?v=whsj-IEX_jI, Slam f Dlam "Slam in the Dark", with the lyrics in Latin script.

29 For more extracts see Caubet forthcoming.

30 See https://www.youtube.com/watch?v=LiMzuCoUAQ4 and http://qgprod.com/2014/og/ mustapha-slameur-feat-lmorphine-magma-mehdi-black-wind-taire-bouche. The text has 545 words in Arabic script and 62 lines. 


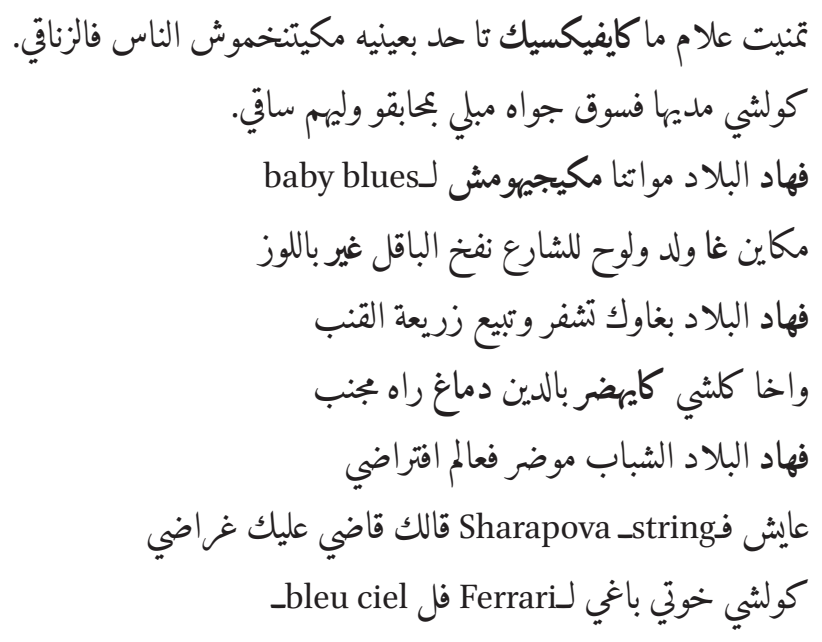

That's what I need

I wish for a world where people do not stare angrily at each other, where they do not spit aggressively at each other in the street,

A world, where everyone minds his own business and cultivates his garden.

In this country, our mothers don't have time to experience the "baby blues",

All you do is give birth and throw him on the street and (for men) swell your balls by eating almonds.

In this country they want you to steal and to sell chips at the corner Even if everyone talks about religion, the minds are filled with sins.

In this country, the youth is lost in a virtual world,

Living with "Sharapova's string", they don't care about the way she plays (tennis)

Everyone, my friends, wants a sky "blue Ferrari"

$$
\begin{aligned}
& \text { Je m'en fous _phone فبت فكاع الحديد. Need for speed } \\
& \text { نص حياتو دايزا نعاس ... النص لاخور Candy Crush } \\
& \text { James Dean } \\
& \text { فهاد البلاد بنادم موضر وخا عندو GPS } \\
& \text { صافي surfé على لـ vague د l'buzz وشري باين و TPS } \\
& \text { مرحبا بيكم كاملين ف قلبان la fista social club }
\end{aligned}
$$




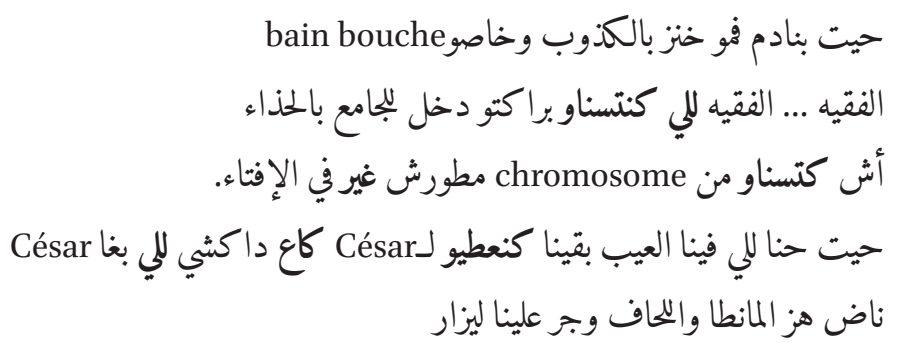

"Need for speed" (a video game) on my “phone, I don't care" I've driven nearly every type of car.

Half his life was spent sleeping, the other half playing "Candy Crush", "James Dean” or Ala' Eddine, who will he choose to be? (I can't swallow this!)

In this country people are lost even if they have a "GPS" Just "surf on the wave of the buzz" and buy Bayn and "TPS" Welcome to you all to the "turn around" your "Vista ${ }^{31}$ social club", everything is weird (Fr. louche)

People's mouths smell bad because of the lies, they need "a mouthwash". The fqih ... the fqih, whose benediction we are waiting for, entered the mosque with his shoes

What can you expect from a "chromosome" who only educates by way of fatwas?

Because what is forbidden to us, we keep giving it a "César",32 everything that needs a "César"

He (a politician) got up and took the election signs and posters, and he stripped us of our sheets (and blankets)

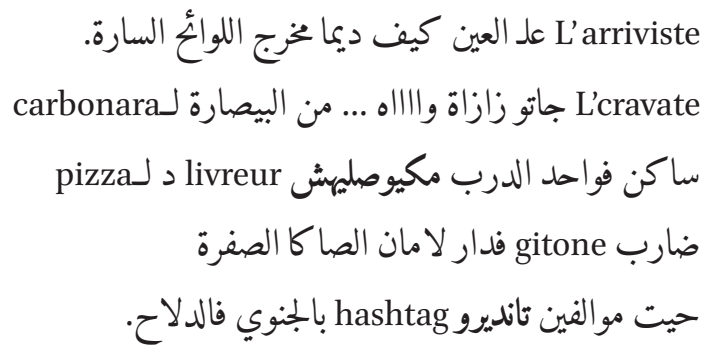

31 Word play between gelleb el fista "turn your jacket around", i.e. "change your mind", and (Buena) Vista Social Club.

32 The "Césars" are the equivalent of the Oscars in France. 


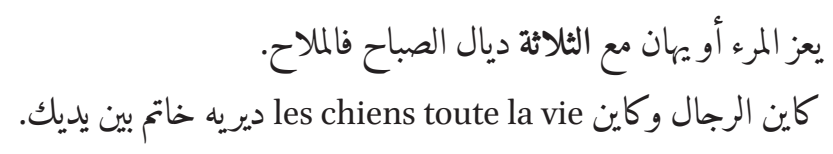

The "arrivist" (social climber) looks very nice, as usual, and the posters are well printed

The "tie" suits him nicely, wow ... from "bisara" ("broad-pea soup", the poor man's meal) to "Carbonara"

He lives in a street where the pizza "delivery guy" does not set foot

He set up a "tent" in Dar El Amane, near the yellow kiosk ${ }^{33}$

Because we are used to publish a "hashtag" when we set a knife in the watermelon

He is a tough guy, but it is impossible to visit the Mellah ${ }^{34}$ at three in the morning.

There are men, and there are "dogs for life" wearing a ring in their hands

Although spoken word is meant to be performed orally, it goes through a phase where it is written down, either on paper or on a keyboard by its author before it is read aloud. Its poetic texts are considered elaborate and pertain to literature.

\section{Remarks on the Spelling of dārija}

The spelling of dārija differs from one author to the other, but they are many more points in common than there are differences. Mouad l7agd, for example, has a much more phonetic approach than Harabish and Don Bader, who wrote down Mustapha Slameur's text.

\section{Regularities}

the texts are not vocalized and bear no diacritics: short vowels, germinations and assimilations are not written down

prepositions $f$ and $b$, are attached to the following nominal group: فهاد البلاد this country".

33 In the popular neighbourhood of Hay Mohammadi in Casablanca; meaning that this the only way he can spend his holiday.

34 In the old medina of Casablanca. 
The spelling of $/ g /$

The $g$ is written $\stackrel{\xi}{\xi}$, as is normally the case in Morocco whether it is etymologically a qaf: (gal lih "he told him"), or a jim: يخلس , كالسين (galsin, yegles "sitting, he sits") (Caubet 1993 I:12).

\section{The future particle}

The future particle in dārija is غادي gadi. ${ }^{35}$ It is often reduced to $\dot{g} a$, leading to the same question as for the preverb $k a$ - (see below); $\dot{g} a$-can be spelled $\dot{\varepsilon}$ or $\dot{ }$. The most common spelling is the short form:

- Mouad uses the full form: غادي نتعرف عليه gadinet3erref3lih "I will get to know

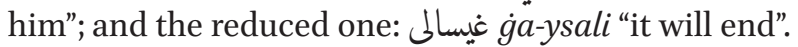

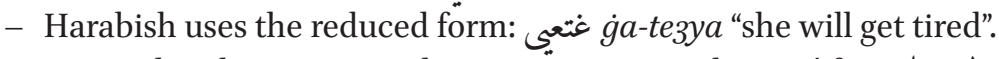

- Mustapha Slameur's text has it written it with an alif: لمن غايشبه le-men $\dot{g} a$ yšbeh "who will he look like?"

\section{Variation}

There is variation in some points of phonology or morphosyntax where there is hesitation, and often the same scriptor is inconsistent in his choices, but never to the point of incomprehension or ambiguity.

\section{Assimilation}

- The article

When the first consonant of the noun is "solar", it is assimilated to the "l" of the preceding article, and is perceived as a gemination. the article can be elided: واحد لحضة wayed-l-leyda > wayed le 1 da; but in the next paragraph, it is written: واحد اللحضة (Mouad "a badge")

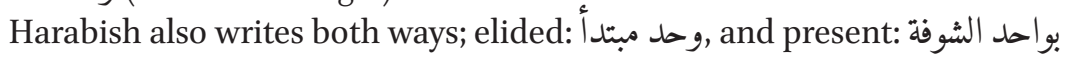
In Mustapha's text, the article is nearly always written الشباب ,الناس en-nas, eš-šabab, with the exception of $(d)$-dmag

35 The active participle of an unused verb * $\dot{g} d a$ "to go". 
- The verb gal and its complement li-h are written as one word: (galih $<$ gal lih Harabish); the final $l$ of the verb and the $l$-preposition are assimilated, producing a gemination, thus written as one letter. This is extremely frequent on the web, in Latin script too: galihom galik

Mustapha's text has a similar case (see negation below): مكيو صليه $m a-k(a)-y$ -

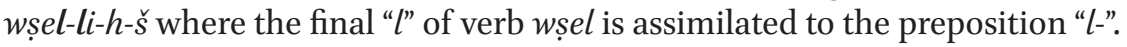

\section{Treatment of interdentals}

Etymological interdentals realized in dārija as stops, are written phonetically, especially in the demonstratives: بحال هكدا رهاد شي ,هادو

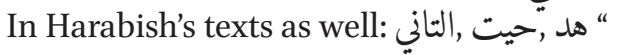

In the slam text, the demonstratives are written as stops, but for the rest, there are some interdentals (that are realized as stops): فهاد البلاد; in the following nominal group we have both: هادي الثقافة

There are other interdentals, like: الثانلاثة and Mustapha Slameur's motto, which is even printed on T-shirts and gives an idea of his position, is: "they lied to us": كذبوا علينا

\section{The relative lli}

The relative lli/elli, is written in slightly different manners.

- Harabish writes it regularly in a simple form: لي but curiously he writes the conjunction melli (> men elli), in an etymological (and complicated) way: من ملى would be a much simpler solution ...

- Mouad writes is like Harabish: لي.

- In Mustapha's texts, it is regularly written with two "l": للي للي

Both spellings are common in dārija.

The variation probably reflects a difference in style or in level of speech, Mouad's first texts being close to oral speech, ${ }^{36}$ whereas the others are more elaborate, even in their writing, with literary ambitions; but, they are all constructed texts. All three of them are used to posting fairly long texts on their

$36 \quad$ As we saw earlier he is presently working on more elaborate texts in view of publication. 
Facebook profile, where they express a point of view or comment an event. Mouad and Mustapha have smartphones from which they can write directly. When asked to read one of his texts, Mouad read it directly from his phone. Harabish writes on a computer.

They all have a long habit of reading and writing in dārija, and so have their numerous followers. On Facebook, the page lyagd has 52,00o followers, Le Slam de Mustapha, 16,00o followers. On Youtube, in February 2016, Mustapha has up to 785,000 views for Chri Chri, 255,000 for Taire-Bouche and over 125,000 for other slams. L7agd has nearly 2,000,00o views (11 February 2016), for the clip Waloo, on which Harabish sings with him. ${ }^{37}$ Tracks from the Waloo 2014 album have from 125,000 to 792,000 views on youtube.

\section{A New Literacy or Just a Step Forward?}

Whether it be in Slam or in elaborate prose texts, dārija is being used and accepted more widely and openly than ever in today's Morocco. The conservative government tried to impose an Arabization of TV programmes, launching a debate on the new Media "Book of technical Specifications" (Fr. "Cahier des charges"), among which the disappearance of French and the massive extension of the use of Arabic from 2012. ${ }^{38}$ The TV channels (mostly 2M) cunningly translated "Arabic" into the massive introduction of "Moroccan Arabic", and developed what they had already started doing from 2009: the dubbing of Turkish and South American series in dārija (see Miller 2012b and Ziamari \& Barontini 2013). They also used darija in magazines and programmes and in political debates.

\section{Conclusion}

As early as June 2014, the journalist Reda Zaireg (2014) wrote a paper in the weekly Telquel, called "Tendance: dārija, langue littéraire" (A new trend: dārija, a literary language. A prison Journal, poverty and exploitation chronicles, memories of a prostitute ... texts written in dārija and posted on social networks are becoming a real literary phenomenon):

37 See https://www.youtube.com/watch?v=dT4yOKnT52I. See the tracks from the album Waloo by Okacha Family, Mouad's band: https://www.youtube.com/channel /UCkaZdJwJxhXqHoRtPLsqdtA.

38 Initially it imposed $80 \%$ of Arabic (and Hassaniya!) and $20 \%$ of Amazigh for Al Aoula. 
For a few months, writing in dārija has had the wind in its sails. With the help of the social networks, it has bypassed the traditional publishers who are reluctant to welcome $d \bar{a} r i j a$, managing to reach its audience directly.

Slam is meant to be performed and heard, whereas blogs and posts are meant to be read on screens. Long texts have to present enough interest - whether through their content or their form (aesthetic, literary) - to foster a desire to read. This reading goes beyond the stage of basic communication and has to be dealt with as a novel passage to literacy.

If "reading is the motivated and fluent coordination of word recognition and comprehension,"39 how does one cope with rapid word recognition when there is variation in the spelling of lexemes and grammatical morphemes for a language - dārija - that has undergone an informal pragmatic D.I.Y. languageplanning with no institution to standardize it? How does one acquire fluency when there hasn't been any school-type learning and when you had to teach yourself to read? In the Moroccan case, this can only be done through practice and experimentation. Gunvor Mejdell (personal communication) suggests the use of the sociological concept of 'conventionalisation', through collective behaviour and repeated usage; youth read and copy from each other, so that separate actions have an impact on the community.

Together with its new visibility in the civil society, intense practice has lead dārija to being written more and more naturally and profusely on Internet, resulting in the first strands of literacy. People are gaining security, fluidity and fluency in their handling of written därija. For the kind of elaborate texts that I have examined here, ${ }^{40}$ it would be interesting to confirm this hypothesis by the organisation of reading tests in order to study the speed of comprehension for completely unknown dārija long prose texts. Over the years, most connected Moroccans have reached a decisive stage where written expression and creation is at work and the exchanges have acquired a deeper dimension. The wave is moving fast with new authors trying out dārija; and among them, Ahlem B., who has been publishing short stories in French on her blog ${ }^{41}$ and on Facebook since 2012. On 28 February 2016, she published the translation of the first story of character Sam Lgaouri in dārija written in Arabic script.

Another kind of elaborate text has appeared under the form of what the authors call "educative" videos that use dārija for extremely technical and legal

\footnotetext{
39 See http://www.readingrockets.org/article/what-reading.

$40 \quad$ Also see Caubet forthcoming 2017.

41 "Ahlem B. vous raconte de folles histoires" on http://www.ahlemb.com.
} 
explications on societal problems. A site like Aji Tfham (An educative Site ${ }^{42}$ tackles a question - like the banning of VoIP communication: ${ }^{43}$ their video is a scientific demonstration in dārija, with fast and precise diction; drawings, words or expressions in Arabic script in dārija (MSA or French when necessary for technical reasons), and long extracts of legal texts in MSA can come to illustrate. In an eight minutes' video, the issue is dealt with and made clear to every citizen: a performance ... in dārija!

But is there, or should there be, an ambition to move into the publishing world? Can literacy on keyboards and screens be exported to printed paper and books? These texts are only published on the internet for the time being. Some authors dream of a printed version, a book, which would give a different social status to their writings; but is the world of publishing ready to cross the (language) barrier? And anyway, Internet offers a much wider audience than could ever be given to a book in Morocco.

Is this kind of practice the gateway in the process of promoting a standard variety, even when the language has no recognition? It is felt as a necessary passage by the authors in their wish to express themselves and share their feelings on screens; they produce long writings in dārija without thinking about their status or their potential role, but as a natural but decisive step in the promotion of their language, dārija.

\section{References}

Arab Social Media Report. 2015. The Dubai School of Government's Governance and Innovation Program. http://www.arabsocialmediareport.com.

Benitez Fernández, Montserrat. 2012. "Telquel: una fuente contemporánea para el studio del árabe marroquí." Pp. 403-417 in De los manuscritos medievales a internet: la presencia del árabe vernáculo en las fuentes escritas, edited by Meouak, M., Sánchez, P., Vicente, Á. Zaragoza, Universidad de Zaragoza.

Berjaoui, Nacer. 2001. "Aspects of the Moroccan Arabic Orthography with Preliminary Insights from the Moroccan Computer-Mediated Communication." Pp. 431-465 in

\footnotetext{
42 "Try and understand, Educative internet site": https://www.facebook.com/AjiTfham/?fref $=$ ts, Mustapha Swinga.

43 VoIP communication was blocked the Moroccan National Telecommunications Regulatory Agency (ANRT) in February 2016. Aji Tfham video has over 250,00o views (accessed 18 Oct. 2016): https://www.youtube.com/watch?list=PL3-8ep118USDASNYWS 3 VwS6RIl _Ddg6Ar\&v=Qt-VSgaebHg. VoIP was finally restored in November 2016 on the occasion of Cop 22 in Marrakech.
} 
Chat-Kommunikation. Sprache, Interaktion, Sozialität \& Identität in synchroner computervermittelter Kommunikation, edited by Michael Beisswenger. Stuttgart: Ibidem Verlag.

Caubet, Dominique. 1993. L'arabe marocain, tomes I (Phonologie et morphosyntaxe) et II (Syntaxe et catégories grammaticales, textes), Paris: Peeters.

Caubet, Dominique. 2001. "Du baba (papa) à la mère, des emplois parallèles en arabe marocain et dans les parlures jeunes en France", in Cahiers d'Etudes Africaines, no. 163-164: 735-748.

Caubet, Dominique. 2004. "L'intrusion des téléphones portables et des SMs dans l'arabe marocain en 2002-2003", in Caubet, D., Bulot, T., Léglise, I. \& Miller, C. (eds.), Parlers Jeunes ici et là-bas, pratiques et représentations. Paris: l'Harmattan. 247-270.

Caubet, Dominique. 2007. "Génération darija!" in EDNA, Estudios de Dialectología Norteafricana y Andalusí 9, Zaragoza, pp. 233-243.

Caubet, Dominique. 2007b. "Moroccan Arabic", in Encyclopedia of Arabic Language \& Linguistics, Volume III, K. Versteegh (Ed.), Leiden: Brill. 273-287.

Caubet, Dominique. 2008. 'From 'Movida' to 'nayda' in Morocco: the use of darija (Moroccan Arabic), in artistic creation at the beginning of the 3 rd millenium." Pp. 113-124 in Between the Atlantic and Indian Oceans, Studies in Contemporary Arabic Dialects, S. Procházka and V. Ritt-Benmimoun (Eds.), Neue Beihefte zur Wiener Zeitschrift für die Kunde des Morgenlandes, Band 4, LIT, Wien.

Caubet, Dominique. 2010b. “'Nayda' or how a pseudo-verb became a much disputed substantive ...", online at De mooiste talen en culturen, Departement Taal en Cultuur Studies, Universiteit van Tilburg, 3p. Now available at: https://www.academia.edu/ 8810799/_Nayda_or_how_a_pseudo-verb_became_a_much_disputed_substantive_.

Caubet, Dominique. 2010a. "La 'nayda' par ses textes." MLM: Magazine Littéraire du Maroc, no. 3-4:99-105. Online at: https://www.academia.edu/6615319/La_nayda _par_ses_textes.

Caubet, Dominique. 2012. "Apparition massive de la darija à l'écrit à partir de 20082009: sur le papier ou sur la toile: quelle graphie? Quelles régularités?” Pp. 377-402 in De los manuscritos medievales a internet: la presencia del árabe vernáculo en las fuentes escritas, edited by Meouak, M., Sánchez, P., Vicente, Á. Zaragoza:Universidad de Zaragoza.

Caubet, Dominique. 2013. "Maroc 2011 - Messagerie instantanée sur l'internet marocain: Facebook, dārija et parlers jeunes." Pp. 63-87 in Evolution des pratiques et des représentations langagières dans le Maroc du zième siècle, edited by Benitez, M., Miller, C., de Ruiter, J. J. \& Tamer, Y. Paris: L' Harmattan.

Caubet, Dominique et Miller, Catherine. 2016. "Quels enjeux sociopolitiques autour de la dārija au Maroc?" Pp. 67-89 in Sini, Chérif \& Laroussi, Foued (dir) Langues et Mutations sociopolitiques au Maghreb, PURH, Colletion 'Plurilectal', Rouen. 
Caubet, Dominique (forthcoming 2017) "New elaborate written forms in dārija: blogging, posting and slamming in Morocco", in Handbook on Arabic Linguistics, edited by Reem Bassiouney et al. London: Routledge.

Gago Gómez, Laura. 2013. "Comment écrire la dārija? La fluctuante proposition des élèves tangérois.” Pp. 177-196 in Evolution des pratiques et des représentations langagières dans le Maroc du zième siècle, edited by Benitez, M., Miller, C., de Ruiter, J. J. \& Tamer, Y. Paris: L' Harmattan.

Hoogland, Jan. 2013. "L'Arabe marocain langue écrite." Pp. 175-188 in Evolution des pratiques et des représentations langagières dans le Maroc du vième siècle, edited by Benitez, M., Miller, C., de Ruiter, J. J. \& Tamer, Y. Paris: L'Harmattan.

Leurs, Koen \& Ponzanesi, Sandra. 2013. "Bits of homeland: Generational and gender transformations of Moroccan-Dutch youth using digital technologies", in Observatorio Journal, Special issue Introducing Media, Technology and the Migrant Family: Media Uses, Appropriations and Articulations in a Culturally Diverse Europe. 089-110.

Meouak, M., Sánchez, P., Vicente, Á. (eds.). 2012. De los manuscritos medievales a internet: la presencia del árabe vernáculo en las fuentes escritas. Zaragoza: Universidad de Zaragoza (Colección Estudios de Dialectología Árabe).

Miller, Catherine. 2011. "Usage de la dārija dans la presse marocaine 2009-2010" in L'Année marocaine, publication en ligne du сјв. http://www.cjb.ma/images/stories/ dārija_Presse_annee_marocaine.pdf.

Miller, Catherine. 2012a. "Observations concernant la présence de l' arabe marocain dans la presse marocaine arabophone des années 2009-2010". Pp. 419-440 in De los manuscritos medievales a internet: la presencia del árabe vernáculo en las fuentes escritas, edited by Meouak, M., Sanchez, P. \& Vicente, A. Zaragoza: Universidad de Zaragoza.

Miller, Catherine. 2012b. "Mexicans speaking in Dârija (Moroccan Arabic): Media, Urbanization and Language Changes in Morocco." Pp. 169-188 in Arabic language \& linguistics, edited by Reem Bassiouney and E. Graham Katz. Washington, D.C.: Georgetown University Press.

Miller, Catherine. 2013. "Evolution des pratiques linguistiques dans les nouvelles radios marocaines." Pp. 89-118 in Evolution des pratiques et des représentations linguistiques dans le Maroc du Xxième siècle, edited by M. Bénitez, C. Miller, J. J. de Ruiter et Y. Tamer. Paris: L'Harmattan.

Miller, Catherine. 2016. "Evolution des pratiques, évolutions des représentations? Petit retour sur le débat autour de la valorisation de la darija au Maroc". Communication présentée au Séminaire LACNAD-IREmAm, Langues de l'Afrique du Nord (berbère/arabe maghrébin): Statut juridique vs statut réel. Evolutions récentes, là-bas et ici.

Moscoso, Francesco, 2009. "Comunidad lingüistica marroquí en los foros y chats. Expresión escrita, norma o anarquía?”. Al-Andalus-Maghreb 16: 209-226. 
Tancrez, Muriel, 13 novembre 2009. "Plus d' un million de Marocains sur Facebook - Au Maroc, Facebook a de beaux jours devant lui." Aufait Maroc. [Not online anymore.] Zaidane Karima. 1980. Emprunt et mélange: produits d'une situation de contact de langues au Maroc, Thèse de zème cycle non publiée, Paris III (dir. David Cohen).

Zaireg, Reda. 2014. “Tendance: Darija, langue littéraire”, Telquel, 17 juin 2014, http:/ telquel.ma/2014/o6/17/tendance-darija-langue-litteraire_139303 (retrieved 16 January 2016).

Ziamari, Karima \& Barontini, Alexandrine. 2013. "Ana: Parlez-vous arabe marocain? Quand les series se réconcilient avec la darija." Pp. 119-143 in Evolution des pratiques et des représentations langagières dans le Maroc du zième siècle, edited by Benitez, M., Miller, C., de Ruiter, J. J. \& Tamer, Y. Paris: L' Harmattan. 